\title{
The risk to human health related to disposal of animal wastes to soil - microbiological and parasitical aspects
}

\author{
J. KACHNIČ ${ }^{1}$, N. SASÁKOVÁ ${ }^{1}$, I. PAPAJOVÁ ${ }^{2}$, K. VESZELITS LAKTIČOVÁ ${ }^{1}$, R. HROMADA $^{1}$, \\ J. HARKABUS ${ }^{1}$, S. ONDRAŠOVIČOVÁ ${ }^{1}$, J. PAPAJ ${ }^{3}$
}

\footnotetext{
${ }^{1}$ University of Veterinary Medicine and Pharmacy in Košice, Komenského 73, 04181 Košice, Slovak Republic;

${ }^{2}$ Institute of Parasitology SAS, Hlinkova 3, 04001 Košice, Slovak Republic, E-mail: papaj@saske.sk; ${ }^{3}$ Technical University of Košice, Letná 9, 04200 Košice, Slovak Republic
}

\begin{abstract}
Summary
The study was conducted to investigate the microbiological and parasitical risk related to the disposal of animal manure to soil by storage of raw pig slurry at temperatures $4{ }^{\circ} \mathrm{C}, 20^{\circ} \mathrm{C}$ and $42{ }^{\circ} \mathrm{C}$ for 115 days. Plate counts of Salmonella typhimurium and number of devitalized non-embryonated model Ascaris suum eggs were determined on days $0,7,12,22,32,40,55,90$ and 115 of storage. At the same intervals level of selected physico-chemical parameters were determined. Microbiological examination showed that $S$. typhimurium survived in the slurry for less than 115 days at $4{ }^{\circ} \mathrm{C}$ and less than 90 days at $20^{\circ} \mathrm{C}$ and $42{ }^{\circ} \mathrm{C}$. Devitalization of $A$. suum eggs increased with temperature and time of storage, but complete devitalization was not achieved even after 115 days at $42{ }^{\circ} \mathrm{C}$. Physico-chemical parameters showed changes related to decomposition processes, but did not allow us to draw definite conclusion regarding their influence on devitalization of pathogens. The results indicate potential risk to human food chain that can be prevented by strict observation of legislative provisions and appropriate treatment of animal manure.
\end{abstract}

Keywords: non-embryonated Ascaris suum eggs; Salmonella typhimurium; raw pig slurry; storage; temperature

\section{Introduction}

In the majority of European countries including Slovakia farm animals are kept on both specialized and intensive farms. The intensive farms are advantageous with regard to economy, profitability, use of technical means and new technologies but also pose some risks to the environment and public health (Manfredi et al., 2011). Of the wastes arising in animal production animal excrements, their treatment and disposal are of particular concern. The optimum way of use of animal excrements is their application to soil that allows one to improve its structure and supplement nutrients important for growing crops (Ondrejková et al., 2012). However, this necessitates proper collection and storage of excrements or other inevitable ways of processing to ensure their appropriate composition and safety. Safe processing of animal excrements is one of the key factors. There are significant microbiological risks related to animal wastes spread onto land subsequently used for crop production or livestock grazing (Lauková et al., 2000; Burton \& Turner, 2003). Unsuitable manipulation, too short or too long storage and intensive use of excrements particularly in the immediate surroundings of farms may frequently result in environmental pollution with respect to noxious gasses and odours, contamination of surface and ground water and hygiene risks related to micro-organisms and various parasitic stages (Nicholson et al., 2005; Venglovský et al., 2006, 2009; Papajová \& Juriš, 2009).

People are in constant contact with soil either directly or indirectly through food, water or air. Soil can act as a carrier or reservoir of important human diseases, particularly intestinal ones (Santamaría \& Toranzos, 2003). Diseases related to soil may be classified, in relation to disease agents, into several groups as follows: (1) diseases related to soil that are caused by occasional pathogens that are normally a part of soil microbiota (e.g. Aspergillus fumigatus), (2) disease agents related to soil resulting in intoxication of food (Clostridium botulinum, $C$. perfringens, Bacillus cereus), (3) diseases caused by pathogenic species originating from soil (C. tetani, Bacillus antracis, C. perfringens) and (4) soil-borne intestinal pathogens that are introduced to soil by human and animal wastes, particularly bacteria, viruses, protozoa and parasitical helminths (Baumgardner, 2012).

With regard to animal wastes we are concerned particularly with representatives of the family Enterobacteriacea, the majority of which have zoonotic character, such as Salmonella sp., Escherichia coli, Mycobacterium sp., Enterococcus sp., Streptococcus sp., Staphylococcus sp. and similar which are threat to both farm animals and man. The 
role of viruses, chlamydia or rickettsia in relation to their spreading by excrements has not been studied extensively contrary to spreading of these agents by sewage sludge. More than 140 enteric viruses can be transmitted by biosolids (Lauková et al., 2003; Venglovský et al., 2009).

Excrements of farm animals are also a source of endoparasites (cysts, eggs, larvae of genera Ascaris sp., Oesophagostomum sp., Trichuris sp., Strongyloides sp., Isospora sp., Eimeria sp., Giardia sp., Balantidium sp., and others) that may cause massive parasitic infections in both specific hosts and non-specific ones, such as man. An important factor in spreading of endoparasitoses is high tenacity of some propagative stages of parasites (Papajová \& Juriš, 2012). It is generally known that some eggs, infectious larvae (L3), oocysts or sporocysts can survive for considerable time, frequently for several years, even under unfavourable environmental conditions. The most dangerous are highly resistant eggs of some parasitic nematodes, e.g. Ascaris spp., Trichuris spp. and coccidial oocysts (Juriš et al., 2000).

After application of manures to land, there is some movement of the pathogens through the soil matrix, both horizontally and vertically (Papajová et al., 2002). In soil, this movement is affected by moisture retaining properties of soil. There are several methods for reducing pathogen levels in biosolids prior to land application, e.g. composting and use of solar drying beds, which reduce water content and devitalize pathogens (Papajová \& Juriš, 2009).

The study was conducted to investigate the microbiological and parasitical risk related to disposal of animal manure to soil by storage of raw pig slurry. The aim of our study was to study survival of $S$. typhimurium and non-embryonated eggs of $A$. suum in the pig slurry stored under laboratory conditions at temperatures $4{ }^{\circ} \mathrm{C}, 20^{\circ} \mathrm{C}$ and $42{ }^{\circ} \mathrm{C}$. Besides the temperature as one of the most important factors, also potential influence of some physico-chemical factors on the survival was also investigated.

\section{Material and methods}

The experiment was carried out on the raw pig slurry obtained from pig farm. The slurry was stored for 115 days in closed plastic containers of volume 5 litre at the following temperatures:

- in a refrigerator at $4{ }^{\circ} \mathrm{C}$,

- in a thermostat at $20^{\circ} \mathrm{C}$,

- in a thermostat at $42^{\circ} \mathrm{C}$.

The devitalization effects of storage were investigated by determination of plate counts of Salmonella typhimurium. $S$. typhimurium was obtained as lyophilised strain $S$. typhimurium SK 14/39 (SZÚ Prague, Czech Republic). After multiplication of the test strains in 24-hour broth culture at $37^{\circ} \mathrm{C}$, we used the cultures of $S$. typhimurium to inoculate the investigated slurry (initial count of $S$. typhimurium $3.6 \times 10^{9}$ CFU.ml ${ }^{-1}$ ).

The $A$. suum eggs used in the experiment were obtained by dissection of distal ends of the uterus of $A$. suum females. The distal uterine ends were then removed to a glass ho- mogenizer and processed. The water suspension of eggs was stored in an Erlenmeyer flask in a refrigerator at $4{ }^{\circ} \mathrm{C}$. To observe the vitality of non-embryonated $A$. suum eggs, polyurethane carriers inoculated with $A$. suum eggs were introduced into containers with pig slurry. A. suum eggs were inoculated by a micropipette into polyurethane carriers, prepared according to Plachý and Juriš (1995), at a dose of 1500 eggs per one carrier. A porous cellular plastic - soft expanded polyurethane, commercially known as a plastic foam, was used as a material for the carriers. It is an additive product of polyisocyanates and compounds with a high content of hydroxylic groups. It consists of a network of interconnected cells, resembling a honeycomb. Its polyurethane structure allows for a sufficient contact of helminth eggs with the environment, preventing them from release and consequently improving their recovery.

The carriers with eggs were exposed to pig slurry of different temperatures for $0,7,12,22,32,40,55,90$ and 115 days. Three samples were taken and analysed at each sampling interval. Vitality of the exposed eggs was determined by 21-day incubation in a thermostat at $26^{\circ} \mathrm{C}$ up to the embryonated stage. The vitality of exposed groups were compared with the control group (suspension of non-embryonated eggs incubated in distilled water).

The following changes in physical and chemical properties of the slurry were monitored: $\mathrm{pH}$, dry matter (DM), chemical oxygen demand (COD) and ammonium ions $\left(\mathrm{NH}_{4}{ }^{+}\right)$.

The samples were examined for the $\mathrm{pH}$ using a $\mathrm{pH}$ electrode (HACH Company, Loveland, Colorado, USA). Dry matter (drying at $105{ }^{\circ} \mathrm{C}$ to a constant weight) and water soluble ammonium nitrogen $\left(\mathrm{NH}_{4}^{+}\right)$by titration (Mulvaney, 1996). COD was determined on the basis of organic substances oxidation in sample by potassium dichromate in sulfuric acid medium during 2-hour boiling in a COD reactor (HACH Company, Loveland, Colorado, USA).

The physical and chemical properties ( $\mathrm{pH}, \mathrm{DM}, \mathrm{COD}$ and $\mathrm{NH}_{4}{ }^{+}$) of pig slurry, as well as the number of damaged eggs, $_{2}$ were expressed as mean values \pm standard deviation $(\bar{x} \pm \mathrm{SD})$.

Significance of differences between experimental and control groups of parasites were determined using Student ttest, ANOVA and Dunnet Multiple Comparison test at the levels of significance $0.05 ; 0.01$ and 0.001 (Statistica 6.0).

\section{Results and discussion}

The microbiological examination of slurry included determination of inoculated S. typhimurium to observe their changes during storage of slurry at different temperatures. $S$. typhimurium was chosen as a model strain since it can cause serious zoonoses disseminated via faecal contamination. According to Reissbrodt et al. (2000), Salmonella species are important food-borne pathogens that represent a significant and increasing public health problem in industrialized countries. There are more than 2000 different Salmonella serotypes. The most common pathogens $S$. enteritidis and $S$. thyphimurium are responsible for nearly half of all illnesses. The persistence of these bacteria in the 
environment (e.g. in soil, water, sewage, etc.) depends on the long-term survival of heavily stressed cells, particularly the so-called viable- but-nonculturable (VNC) organisms, that cannot grow on conventional laboratory plating media but may revive in vivo and cause diseases (Chmielewski \& Frank, 1995; Rice et al., 2003; Brandl et al., 2006). Salmonella-contaminated vegetables and fruits were recently identified as a widespread source of human infection. This facultative endopathogen enters and replicates in host cells and actively suppresses host immune responses. Although Salmonella survives on plants, the underlying bacterial infection mechanisms are only poorly understood. Schikora et al. (2008) showed that Salmonella can actively invade and proliferate in Arabidopsis plants and cause disease. Although the possibility of survival of Salmonella in soil for more than 900 days was known earlier, there were questions about its pathogenicity for roots and other plant parts. However, in 2008 Vienna Plant Molecular Biology Laboratory, in collaboration with French laboratories concluded that Salmonella is able to actively penetrate the soil to the root hairs, and so behave like a typical plant pathogen. In the USA, there was proven infection with Salmonella from tomatoes. The disease was caused by the ingestion of tomatoes from farms that used to fertilize organic residues containing both Salmonella and other Enterobacteriaceae. In the U.S., tomatoes have become the most implicated vehicle for produce associated salmonellosis with 12 outbreaks since 1998 (Barak \& Liang, 2008). Therefore, the risk to public health arising from the application of insufficiently treated animal manure to the soil may be higher than detected by common methods. Results of microbiological examination of pig slurry during 115 days of storage at three different temperatures are presented in Fig. 1.

The initial concentration of the tested $S$. typhimurium strain $\left(3.6 \times 10^{5} \mathrm{CFU} \cdot \mathrm{ml}^{-1}\right)$ in pig slurry stored at $4{ }^{\circ} \mathrm{C}$ decreased by day 90 by three orders of magnitude $\left(3.1 \times 10^{2}\right.$ CFU.ml $\left.{ }^{-1}\right)$ and on day 115 of storage the test strain was no more recovered. The tested strain survived in slurry for less than 115 days at $20^{\circ} \mathrm{C}$. A marked decrease by 7 orders of magnitude (to $6.3 \times 10^{2}$ CFU.ml ${ }^{-1}$ ) was observed on day 32 and from this day the test strain was investigated only qualitatively. The most marked decrease in plate counts of test bacteria was recorded in pig slurry stored at $42{ }^{\circ} \mathrm{C}$ (Fig. 1). The survival of pathogens in animal manures and manure slurries is often studied under controlled laboratory conditions. Kudva et al. (1998) noted that survival of pathogens in laboratory studies were was generally lower than those observed in field studies.

Our results showed decreased survival of $S$. typhimurium in pig slurry during storage at $20{ }^{\circ} \mathrm{C}$ and $42{ }^{\circ} \mathrm{C}$. This indicated that the viability of bacteria in stored pig slurry was affected first of all by the temperature during the storage. Increased temperature is an important factor contributing to the devitalization of indicator micro-organisms. Similar results on survival of $S$. typhimurium and indicator microorganisms in stored pig slurry solids were obtained by Plachá et al. (2001, 2008).

Himathongkham et al. (1999) stored cattle manure and manure slurry at $4{ }^{\circ} \mathrm{C}, 20^{\circ} \mathrm{C}$ and $37^{\circ} \mathrm{C}$ and observed survival of $E$. coli $\mathrm{O} 157: \mathrm{H} 7$ and $S$. typhimurium and observed decimal reduction times from 6 days to 3 weeks in manure and from 2 days to 5 weeks in slurry. The main effects of time, as well as temperature, were pronounced with the rapidest destruction at $37{ }^{\circ} \mathrm{C}$. According to these authors, the observed order of destruction makes it possible to predict storage conditions (temperature and time) that will lead to a predetermined level of reduction of the two pathogens.

Arrus et al. (2006) observed influence of temperature on $S$. typhimurium and another three Salmonella serovars in hog slurry from different production phases stored at $4{ }^{\circ} \mathrm{C}$, $25^{\circ} \mathrm{C}$ or $37{ }^{\circ} \mathrm{C}$. Salmonella survived for $>300$ days at $4{ }^{\circ} \mathrm{C}$. At higher temperatures, the survival was significantly lower. The authors concluded that while Salmonella did not grow in hog manure, storage reservoir temperatures

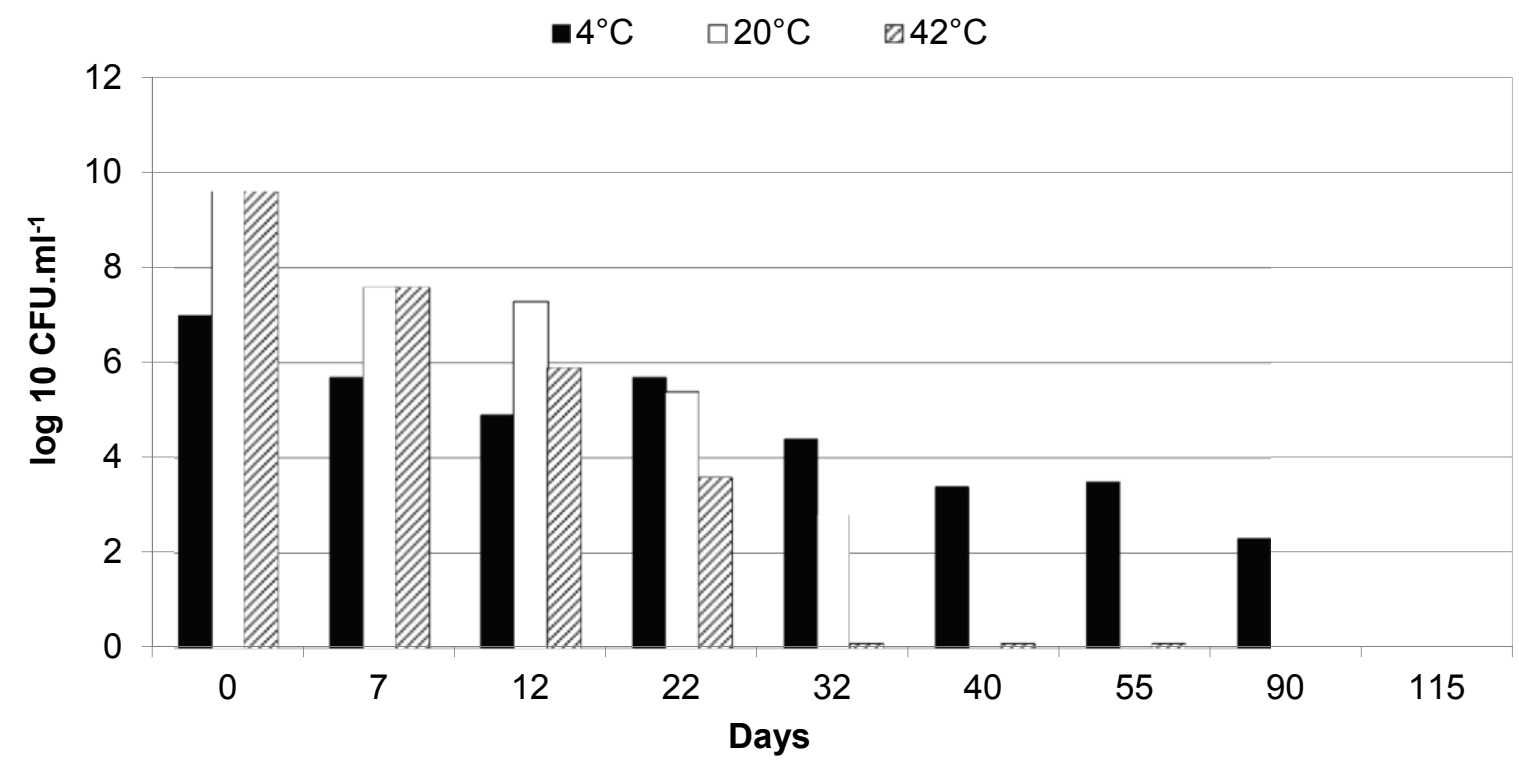

Fig. 1. Survival of Salmonella typhimurium in the raw pig slurry stored at three different temperatures 
Table 1. Survival of non-embryonated model A. suum eggs in raw pig slurry stored at three different temperatures

\begin{tabular}{cccc}
\hline Exposure time (days) & \multicolumn{2}{c}{ Devitalized eggs of $\boldsymbol{A}$. suum $(\overline{\boldsymbol{x}} \mathbf{\%} \pm \mathbf{S D})$} \\
\cline { 2 - 4 } & $\mathbf{4}^{\circ} \mathbf{C}$ & $\mathbf{2 0}{ }^{\circ} \mathbf{C}$ & $\mathbf{4 2}^{\circ} \mathbf{C}$ \\
\hline $\mathbf{0}$ & $15.55 \pm 2.52$ & $10.13 \pm 3.17$ & $14.90 \pm 4.06$ \\
$\mathbf{7}$ & $16.86 \pm 2.39$ & $16.72 \pm 1.38$ & $74.30 \pm 0.82^{* * *}$ \\
$\mathbf{1 2}$ & $20.33 \pm 9.31$ & $17.17 \pm 5.74$ & $92.39 \pm 4.95^{* *}$ \\
$\mathbf{2 0}$ & $17.04 \pm 11.25$ & $16.86 \pm 3.64$ & $99.23 \pm 1.09^{* * *}$ \\
$\mathbf{3 2}$ & $21.54 \pm 16.67$ & $26.90 \pm 4.38$ & $92.85 \pm 10.10^{* *}$ \\
$\mathbf{4 0}$ & $22.87 \pm 4.06$ & $21.85 \pm 10.69$ & $96.15 \pm 5.44^{* *}$ \\
$\mathbf{5 5}$ & $24.90 \pm 1.28^{*}$ & $23.81 \pm 13.46$ & $98.24 \pm 2.48^{* * *}$ \\
$\mathbf{9 0}$ & $25.87 \pm 5.84$ & $36.28 \pm 10.91$ & $95.83 \pm 5.89^{* *}$ \\
$\mathbf{1 1 5}$ & $26.97 \pm 5.14$ & $37.65 \pm 8.34$ & $99.65 \pm 1.34 * * *$ \\
\hline $\mathbf{C o n t r o l}$ & $14.14 \pm 0.82$ & $15.14 \pm 0.92$ & $14.14 \pm 0.22$ \\
\hline
\end{tabular}

would facilitate Salmonella survival over winter enabling contamination of fields at spring application. Since untreated liquid hog manure may contain Salmonella, manure should be held for 60 days without commingling with fresh manure in reservoirs before application to fields with actively growing crops to minimize the risk of plant and soil contamination by Salmonella.

Recently the emergence of Salmonella strains resistant to antimicrobials, often as a result of antimicrobial usage in animals, is a public health hazard of great concern (Venglovský et al., 2009). Successful control must focus on a range of preventive actions because there is no simple 'silver bullet' solution to reduce Salmonella contamination. Key to controlling Salmonella is to follow the general rules that have been successfully applied to other infectious diseases (Plym Forshell \& Wierup, 2006).

Parasite survival in animal manures may also be related to temperature, but the trends are not as pronounced as those reported for bacterial pathogens. This is likely due to their ability to form cysts and oocysts for protection from environmental pressures. Olson (2003) noted that A. suum eggs are highly resistant to inactivation in faeces, potentially remaining infectious for years. This is very important also with regard to the fact that $A$. suum is a zoonotic parasite. However, these environments may also be hostile, as they may harbour both predators and competitors, or produce toxic components, that may reduce the pathogen viability. For instance, free ammonia naturally produced by hydrolysis of urea and in decomposing manure, can be biocidal at high concentration. A. suum infects pigs and is of major economic significance due to production losses linked to reduce feed conversion efficiency and losses to the mean industry associated with the condemnation of "milk-spot" livers (Dubinský et al., 2000). Ascaris infects over a quarter of the world's human population (1.47 billion people worldwide) and clinically affects $\sim 335$ million people (Crompton, 1999).

The above-mentioned helminthozoonoses are classified among epidemiologically "low-risk" parasitozoonoses, because the propagative stages develop in the outdoor environment into the infectious stage and potentially secondarily contaminate the food chain. Therefore, direct contact with an infected animal, but also contaminated environment, or contaminated food chain (water, vegetables) are considered as a potential risk factor (Papajová \& Juriš, 2012).

For the above-mentioned reasons, our studies concentrated also on survival of non-embryonated $A$. suum eggs in raw pig slurry. Devitalization of non-embryonated $A$. suum eggs, inserted into slurry on polyurethane carriers is presented in Table 1.

At $4{ }^{\circ} \mathrm{C}$, the number of devitalized eggs increased with the length of storage with the exception of day 20 from 15.55 $\pm 2.52 \%$ on day 0 up to $26.97 \pm 5.14 \%$ on day 115 . This was almost double decrease compared to the control (14.14 $\pm 0.82 \%)$. The difference between storage in slurry and distilled water was significant $(\mathrm{P}<0.05)$ after 55 days of storage.

Table 2. Changes of $\mathrm{pH}$ in raw pig slurry stored at different temperatures

\begin{tabular}{cccc}
\hline Exposure time (days) & pH ( $\mathbf{\boldsymbol { x }} \mathbf{\%} \mathbf{\text { SD}})$ & \\
\cline { 2 - 4 } & $\mathbf{4}^{\mathbf{0}} \mathbf{C}$ & $\mathbf{2 0}^{\mathbf{0}} \mathbf{C}$ & $\mathbf{4 2}^{\mathbf{0}} \mathbf{C}$ \\
\hline $\mathbf{0}$ & $6.95 \pm 0.11$ & $6.95 \pm 0.11$ & $6.95 \pm 0.11$ \\
$\mathbf{7}$ & $6.97 \pm 0.03$ & $7.09 \pm 0.09$ & $7.36 \pm 0.01$ \\
$\mathbf{1 2}$ & $7.04 \pm 0.07$ & $7.25 \pm 0.15$ & $8.01 \pm 0.02$ \\
$\mathbf{2 0}$ & $6.93 \pm 0.08$ & $7.10 \pm 0.03$ & $8.38 \pm 0.13$ \\
$\mathbf{3 2}$ & $7.08 \pm 0.08$ & $7.36 \pm 0.14$ & $8,74 \pm 0,06$ \\
$\mathbf{4 0}$ & $7.22 \pm 0.07$ & $7.43 \pm 0.26$ & $8.55 \pm 0.02$ \\
$\mathbf{5 5}$ & $7.45 \pm 0.09$ & $8.00 \pm 0.39$ & $8.94 \pm 0.03$ \\
$\mathbf{9 0}$ & $8.33 \pm 0.48$ & $8.13 \pm 0.27$ & $9.10 \pm 0.07$ \\
$\mathbf{1 1 5}$ & $8.35 \pm 0.58$ & $8.55 \pm 0.17$ & $9.35 \pm 0.05$ \\
\hline
\end{tabular}


Table 3. Changes of dry matter (DM) in raw pig slurry stored at different temperatures

\begin{tabular}{cccc}
\hline Exposure time (days) & \multicolumn{3}{c}{ DM $\left(\overline{\boldsymbol{x}} \mathbf{g . k \mathbf { k g } ^ { - \mathbf { 1 } } \pm \mathbf { S D } )}\right.$} \\
\cline { 2 - 4 } & $\mathbf{4}^{\circ} \mathbf{C}$ & $\mathbf{2 0}{ }^{\circ} \mathbf{C}$ & $\mathbf{4 2}^{\circ} \mathbf{C}$ \\
\hline $\mathbf{0}$ & $28.00 \pm 6.26$ & $28.00 \pm 6.26$ & $28.00 \pm 6.26$ \\
$\mathbf{7}$ & $27.17 \pm 4.45$ & $19.45 \pm 2.09$ & $18.05 \pm 3.12$ \\
$\mathbf{1 2}$ & $19.00 \pm 1.73$ & $9.00 \pm 1.32$ & $14.17 \pm 2.25$ \\
$\mathbf{2 0}$ & $22.75 \pm 4.45$ & $16.00 \pm 3.45$ & $17.67 \pm 2.08$ \\
$\mathbf{3 2}$ & $22.75 \pm 5.06$ & $12.00 \pm 4.00$ & $12.67 \pm 3,06$ \\
$\mathbf{4 0}$ & $2.22 \pm 1.89$ & $22.67 \pm 4.16$ & $14.33 \pm 1.16$ \\
$\mathbf{5 5}$ & $18.25 \pm 3.40$ & $18.00 \pm 5.00$ & $21.00 \pm 3.61$ \\
$\mathbf{9 0}$ & $15.33 \pm 0.58$ & $14.66 \pm 8.08$ & $15.67 \pm 6.67$ \\
$\mathbf{1 1 5}$ & $15.09 \pm 1.23$ & $13.09 \pm 4.12$ & $12.89 \pm 1.05$ \\
\hline
\end{tabular}

Similar but more marked decrease in survival was observed at $20^{\circ} \mathrm{C}$ between day 0 and 115 when only $62.35 \pm$ $8.34 \%$ of viable eggs remained in the slurry compared to $84.86 \pm 0.92 \%$ of viable eggs kept in distilled water. The viability of non-embryonated eggs of $A$. suum varied considerably during storage at this temperature.

Observations at $42{ }^{\circ} \mathrm{C}$ showed still more rapid devitalization of $A$. suum eggs exposed to pig slurry. By the end of the experiment $99.65 \pm 1.34 \%$ of eggs were devitalized compared to $14.14 \pm 0.22 \%$ in the control. Significant differences in the number of devitalized eggs were observed on days 12, 40 and $90(\mathrm{P}<0.01)$ and 7, 20, 55 and $115(\mathrm{P}<0.001)$ of storage.

Similar results of helminths eggs devitalization in slurry stored anaerobically were also presented by Juriš et al. (1996). Polprasert and Valencia (1981) found $27 \%$ inactivation of Ascaris eggs at $25{ }^{\circ} \mathrm{C}$ after $48 \mathrm{~h}$ treatment of excreta whereas in the same period Pecson et al. (2006) found $29 \%$ inactivation at $30{ }^{\circ} \mathrm{C}$. Plachý et al. (1996) found only $4 \%$ inactivation of Ascaris eggs after 7 day of treatment at $21-25{ }^{\circ} \mathrm{C}$. Parasites, spore-forming bacteria and some types of viruses generally persist for the longest periods in the environment. In general, survival of pathogens in soil increases when manures are incorporated into the soil rather than left on the surface which may be related to decreased exposure to UV radiation, temperature extremes and desiccation and increased availability of nutrients (Hutchinson et al., 2005).

Besides the temperature also changes in physico-chemical properties (particularly $\mathrm{pH}, \mathrm{DM}, \mathrm{COD}$, ammonia, total phosphorus and total nitrogen) of slurry could affect the vitality of model non-embryonated $A$. suum eggs at longterm storage (Katakam et al., 2013).

Our study showed that the number of devitalized Ascaris eggs generally increased with the length of storage and the temperature. However, considerable number of Ascaris eggs remained viable even after 115 days of storage at $4{ }^{\circ} \mathrm{C}$ and $20{ }^{\circ} \mathrm{C}$. Only at $42{ }^{\circ} \mathrm{C}$ more than $90 \%$ of eggs were devitalized after 12 days of storage. However, such temperature can only rarely be reached in animal slurries; thus the risk of persistence of this zoonotic parasite is really high. Separation of pig slurry into solid and liquid fractions is gaining importance as a way to manage increasing volumes of slurry. This is a common process in wastewater treatment plants. The viability of $A$. suum eggs, a conservative indicator of faecal pollution, and its association with ammonia was investigated in separated liquid slurry in comparison with raw slurry (Katakam et al., 2013). Initial analysis of helminth eggs in the separated liquid slurry revealed 47 Ascaris eggs per gram. At $25^{\circ} \mathrm{C}$, egg viability declined to zero with a similar trend in both raw slurry and the separated liquid slurry by day 308 , a time when at $5{ }^{\circ} \mathrm{C}$ $88 \%$ and $42 \%$ of the eggs were still viable in separated liquid slurry and raw slurry, respectively. The poorer survival at $25^{\circ} \mathrm{C}$ was correlated with high ammonia contents in the range of $7.9-22.4 \mathrm{mM}$ in raw slurry and $7.3-23.2$ $\mathrm{mM}$ in a liquid slurry compared to $3.2-9.5 \mathrm{mM}$ in raw slurry and $2.6-9.5 \mathrm{mM}$ in liquid slurry stored at $5{ }^{\circ} \mathrm{C}$. The study demonstrates that, at $5^{\circ} \mathrm{C}, A$. suum eggs have a higher viability in separated liquid slurry as compared to raw slurry. The hygiene aspect of this needs to be further investigated when separated liquid slurry or separated

Table 4. Changes of chemical oxygen demand (COD) in raw pig slurry stored at different temperatures

\begin{tabular}{|c|c|c|c|}
\hline \multirow[t]{2}{*}{ Exposure time (days) } & \multicolumn{3}{|c|}{$\mathrm{COD}_{\mathrm{Cr}}\left(\bar{x} \mathrm{~g} \cdot \mathrm{kg}^{-1} \mathrm{DM} \pm \mathrm{SD}\right)$} \\
\hline & $4^{\circ} \mathrm{C}$ & $20^{\circ} \mathrm{C}$ & $42{ }^{\circ} \mathrm{C}$ \\
\hline $\mathbf{0}$ & $804.00 \pm 2.73$ & $804.00 \pm 21.11$ & $804.00 \pm 21.11$ \\
\hline 7 & $927.17 \pm 3.51$ & $1145.45 \pm 42.09$ & $1267.05 \pm 43.12$ \\
\hline 12 & $1205.11 \pm 2.53$ & $1767.00 \pm 66.18$ & $1429.17 \pm 92.25$ \\
\hline 20 & $800.34 \pm 1.11$ & $1288.04 \pm 25.16$ & $778.17 \pm 24.74$ \\
\hline 32 & $752.14 \pm 1.92$ & $1358.10 \pm 54.89$ & $677.57 \pm 10.41$ \\
\hline 40 & $1850.22 \pm 2.41$ & $821.92 \pm 49.73$ & $714.33 \pm 1.16$ \\
\hline 55 & $1033.25 \pm 2.04$ & $844.34 \pm 20.97$ & $580.98 \pm 31.61$ \\
\hline 90 & $900.33 \pm 3.58$ & $500.16 \pm 17.67$ & $475.27 \pm 14.48$ \\
\hline 115 & $734.09 \pm 2.89$ & $489.09 \pm 42.12$ & $222.89 \pm 10.05$ \\
\hline
\end{tabular}


Table 5. Changes of $\mathrm{NH}_{4}^{+}$in raw pig slurry stored at different temperatures

\begin{tabular}{|c|c|c|c|}
\hline \multirow[t]{2}{*}{ Exposure time (days) } & \multicolumn{3}{|c|}{$\mathrm{NH}_{4}^{+}\left(\bar{x} \mathrm{~g}^{+\mathrm{kg}^{-1}} \mathrm{DM} \pm \mathrm{SD}\right)$} \\
\hline & $4^{\circ} \mathrm{C}$ & $20^{\circ} \mathrm{C}$ & $42{ }^{\circ} \mathrm{C}$ \\
\hline $\mathbf{0}$ & $50.00 \pm 21.11$ & $50.00 \pm 21.11$ & $50.00 \pm 21.11$ \\
\hline 7 & $71.17 \pm 14.45$ & $117.98 \pm+12.67$ & $74.46 \pm 4.20$ \\
\hline 12 & $63.41 \pm 16.53$ & $200.45 \pm 50.83$ & $100.43 \pm 8.21$ \\
\hline 20 & $48.24 \pm 22.74$ & $81.14 \pm 5.34$ & $78.77 \pm 2.74$ \\
\hline 32 & $122.09 \pm 20.23$ & $225.45 \pm 54.23$ & $215.13 \pm 14.12$ \\
\hline 40 & $700.22 \pm 32.30$ & $58.12 \pm 7.43$ & $93.14 \pm 8.56$ \\
\hline 55 & $78.51 \pm 56.80$ & $62.31 \pm 12.89$ & $33.45 \pm 1.67$ \\
\hline 90 & $87.56 \pm 42.58$ & $33.24 \pm 2.42$ & $3.12 \pm 0.74$ \\
\hline 115 & $84.13 \pm 21.23$ & $27.11 \pm 1.06$ & $0.56 \pm 0.01$ \\
\hline
\end{tabular}

solids are used to fertilize pastures or crops. This hazard increases when raw slurry is used for fertilization of soil or pastures. In the outer environment, eggs develop into infective stages and may also infect other susceptible animals (ruminants).

Besides temperature and time of storage, the survival of pathogens in the slurry may well depend on factors other than temperature and duration of heat treatment, e.g. moisture content, free ammonia concentration, $\mathrm{pH}$, the presence of other micro-organisms and other physicochemical properties (Turner, 2002; Venglovský et al., 2006) This was the reason why we carried out also physico-chemical examination. The stored pig slurry was subjected also to physico-chemical examination which included the determination of $\mathrm{pH}$, dry matter (DM), chemical oxygen demand (COD) and ammonium ion $\left(\mathrm{NH}_{4}^{+}\right)$. Results are presented as $\bar{x} \% \pm \mathrm{SD}$ in Tables $2-5$. With some fluctuations, the $\mathrm{pH}$ level increased throughout the storage at all three temperatures. On the other hand, we observed a decrease in DM content toward the end of storage. $\mathrm{NH}_{4}{ }^{+}$level fluctuated considerably, and the final level of this parameter differed between the treatments. The COD generally decreased.

In our study, we observed a $\mathrm{pH}$ increase in stored pig slurry at all three temperatures. This increase was not in correlation with the level of ammonium which varied considerably. This could be due to its release as ammonia and the related decrease in total nitrogen by the end of the experiment except for temperature $4{ }^{\circ} \mathrm{C}$. DM content decreased according to expectations, so did other parameters, which may be related to production and release of some volatile compounds during the storage. The processes that take place in slurry are, however, very complex, and the extent of our examinations did not allow us to draw any definite conclusions in this respect.

\section{Conclusion}

Legislation in advanced countries requires acceptable procedures for the disposal, processing and application of animal manures. However, there are still aspects that may raise some risk for safety of human food chain and require further investigations. The best way is to put stress on preventive actions and measures that may eliminate any known or suspected danger resulting from pathogens pre- sent in animal manures applied to the soil that is used for animal grazing or growing of crops for human consumption.

\section{Acknowledgements}

This study was financially supported by the project VEGA No. 2/0140/13.

\section{References}

Arrus, K. M., Holley, R. A., Ominski, K. H., TenutA, M., Blank, G. (2006): Influence of temperature on Salmonella survival in hog manure slurry and seasonal temperature profiles in farm manure storage reservoirs. Livest. Sci., 102: 226 - 236. DOI: 10.1016/j.livsci.2006.03.021

BARAK, J. D., LIANG, A.S. (2008): Role of soil, crop debris, and a plant pathogen in Salmonella enterica contamination of tomato plants. PLOS ONE, 3: e1657. DOI: 10.13 71/journal.pone.0001657

BAUMGARDNER, D. J. (2012): Soil-related bacterial and fungal infections. J. Am. Board Fam. Med., 25(5): 734 744. DOI: $10.3122 /$ jabfm.2012.05.110226

BRANDL, M. T. (2006): Fitness of human enteric pathogens on plants and implications for food safety. Annu. Rev. Phytopathol., 44: 367 - 392. DOI: 10.1146/annurev.phyto. 44.070505.143359

Burton, C. H., TURNER, C. (2003): Manure management treatment strategies for sustainable agriculture. $2^{\text {nd }}$ Edition, Silsoe Research Institute, Wrest Park, Silsoe, Bedford, UK, $490 \mathrm{pp}$.

CHMIELEWSKI, R.A.N., FrANK, J. F. (1995): Formation of viable but nonculturable Salmonella during starvation in chemically defined solutions. Lett. Appl. Microbiol., 20 (6): 380 - 384. DOI: 10.1111/j.1472-765X.1995.tb01326.x CROMPTON, D. W. (1999): How much human helminthiasis is there in the world? J. Parasitol., 85: $397-403$. DOI: $10.2307 / 3285768$

Dubinský, P., Krupicer, I., LeVkUt, M., ŠvickÝ, E., DVOrožŇÁKovÁ, E., REVAJOVÁ, V., VAsilkovÁ, Z., KovÁČ, G., REITEROVÁ, K., LENHARDT, L', ONDREJKA, R., PAPAJOVÁ, I., MONCOL, D. J. (2000): Influence of Ascaris suum infection on ruminants. In: DUBINSKÝ, P., JURIŠ, P., MonCOL, D. J. (Eds): Environmental protection against the spread of pathogenic agents of diseases through the 
wastes of animal production in the Slovak Republic. Harlequine, Ltd., Košice, pp. 143 - 160

Hutchinson, T. F., Sutherland, E. K., Yaussy, D. A. (2005): Effects of repeated prescribed fires on the structure, composition, and regeneration of mixed-oak forests in Ohio. Forest Ecol. Manag., 218 (1 - 3): 210 - 228. DOI: 10.1016/j.foreco.2005.07.011

HimathongKham, S., Bahari, S., RiemanN, H., Cliver, D. (1999): Survival of Escherichia coli O157:H7 and Salmonella typhimurium in cow manure and cow slurry. FEMS Microbiol. Lett., 178: 251 - 257. DOI: 10.1111/j.1574-6968.1999.tb08684.x

Juriš, P., TÓTh, F., LAuKOVÁ, A., PlachÝ, P., DubinskÝ, P., SOKOL, J. (1996): Survival of model bacterial strains and helminth eggs in the course of mesophilic anaerobic digestion of pig slurry. Vet. Med. - Czech., 41: 149 - 153

JURIŠ, P., RATAJ, D., ONDRAŠOVIČ, M., SOKOL, J., NOVÁK, P. (2000): Sanitary and ecological requirements on recycling of organic wastes in agriculture. Vyd. Michala Vaška, Prešov, 178 pp. (In Slovak)

Katakam, K. K., RoepstorfF, A., Popovic, O., Kyvsgaard, N. C., Thamsborg, S. M., Dalsgaard, A. (2013): Viability of Ascaris suum eggs in stored raw and separated liquid slurry. Parasitology, 140 (3): 378 - 384. DOI: $10.1017 / \mathrm{S} 0031182012001722$

Kudva, I. T., Blanch, K., Hodve, C. J. (1998): Analysis of Escherichia coli O157:H7 survival in ovine or bovine manure and manure slurry. Appl. Environ. Microbiol., 64: $3166-3174$

LAUKOVÁ A., JURIŠ P., VASILKOVÁ Z. (2000): Contamination and survival of pathogenic agents as well as other microbial agents in the wastes from pig farms. In: DUBINSKÝ P., JURIŠ P., MONCOL D. J. (Eds): Environmental protection against the spread of pathogenic agents of diseases through the wastes of animal production in the Slovak Republic. Parasitological Institute, SAS, Košice, pp. $55-78$

Lauková, A., Guba, P., Nemcová, R., Vasilková, Z. (2003): Reduction of Salmonella in gnotobiotic japanese quails caused by the enterocin A-producing EK13 strain of Enterococcus faecium. Vet. Res. Commun., 27 (4): 275 280. DOI: $10.1023 / A: 1024027923824$

MANFredi, M. T., Di CERBO, A. R., ZANZANI, S., Moriggia, A., Fattori, D., Siboni, A., BonazzA, V., FILICE, C., BRUNETTI, E. (2011): Prevalence of echinococcosis in humans, livestock and dogs in northern Italy. Helminthologia, 48 (2): 59 - 66. DOI 10.2478/s11687-0110011-9

Mulvaney, R. L. (1996): Nitrogen - inorganic forms. In SpARKS, D. L. (Ed) Methods of Soil Analysis. Madison, WI: SSSA Inc., pp. 1123 - 1184

Nicholson F. A, Groves S. J, Chambers B. J. (2005): Pathogen survival during livestock manure storage and following land application. Bioresour. Technol., 96: $135-$ 143. DOI: $10.1016 /$ j.biotech.2004.02.030

OLsON, M. E. (2001): Human and animal pathogens in manure. In Livestock Options for the Future National Conference, Winnipeg, Manitoba, Canada, June 25 - 27,
2001. Agriculture and Agri-Food Canada. Retrieved from http://www.stopthehogs.com/pdf/pathogens.pdf ONDREJKOVÁ, A., ČERNEK, L'., PROKEŠ, M., ONDREJKA, R., HuRníkOVÁ, Z., TAKÁČOVÁ, D. (2012): Monitoring of Ascaris suum in slaughter pigs during $2000-2009$ in Slovakia. Helminthologia, 49 (4): 221 - 224. DOI: 10.2478/s11687-012-0041-y

PAPAJOVÁ, I., JuRIŠ, P., LAUKOVÁ, A., RATAJ, D., VASILKOVÁ, Z., ILAVSKÁ, I. (2002): Transport of Ascaris suum eggs, bacteria and chemical pollutants from livestock slurry through the soil horizon. Helminthologia, 39 (2): 77 - 85

PAPAJOVÁ, I., JURIŠ, P. (2009): The effect of composting on the survival of parasitic germs. In: PEREIRA, J. C., BOLIN, J. L. (Eds) Composting: Processing, Materials and Approaches. New York: Nova Science Publishers, pp. 124 - 171 PAPAJOVÁ, I., JURIŠ, P. (2012): The sanitation of animal waste using anaerobic stabilisation. In: KUMAR, S., BHARTI, A. (Eds) Management of organic waste. Rijeka: InTech, pp. $49-68$

Pecson, B. M., Barrios, J. A., Johnson, D. R., Nelson, K. L. (2006): A real-time PCR method for quantifying viable Ascaris eggs using the first internally transcribed spacer region of ribosomal DNA. Appl. Environ. Microbiol., 72 (12): 7864 - 7872. DOI: 10.1128/AEM.01983-06 Plachá, I., Venglovský, J., SAsáková, N., Svoboda, I. F. (2001): The effect of summer and winter seasons on the survival Salmonella typhimurium and indicator microorganisms during the storage of solid fraction of pig slurry. $J$. Appl. Microbiol., 91 (6): 1036 - 1043. DOI: 10.1046/j.1365-2672.2001.01471.X

PlachÁ, I., VenglovskÝ, J., MaKovÁ, Z., Martinéz, J. (2008): The elimination of Salmonella typhimurium in sewage sludge by aerobic mesophilic stabilization and lime hydrated stabilization. Bioresource Technol., 99 (10): 4269 - 4274. DOI: 10.1016/j.biortech.2007.08.056

PLACHÝ, P., JURIŠ, P. (1995): Use of polyurethane carrier for assessing the survival of helminth eggs in liquid biological sludges. Vet. Med., 40 (10): 323 - 326

PlachÝ, P., JURiš, P., PlaChÁ, I, VENGLOVSKÝ, J. (1996): Use of hydrated lime for disinfection of the indicator pathogens Salmonella typhimurium and Ascaris suum in sewage sludge. Vet. Med., 41: 255 - 259

PlyM Forshell, L., WIERUP, M. (2006): Salmonella contamination: a significant challenge to the global marketing of animal food products. Rev. Sci. Tech. Off. Int. Epiz., 25 (2): $541-554$

POLPRASERT, C., VAlenCIA, L. G. (1981): The inactivation of faecal coliforms and Ascaris ova in faeces by lime. Water Res., 15: 31 - 36

Rice, D. H., HANCOCK, D. D., RoOzen, P. M., SzYMANSKI, M. H., Scheenstra, B. C., CADy, K. M., Besser, T. E., CHUdeK, P. A. (2003): Household contamination with Salmonella enterica. Emerg. Infect. Dis., 9(1): 120 - 122. DOI: 10.3201/eid0901.020214

Reissbrodt, R., HeIER, H., TschäPe, H., Kingsley, R. A., WILLIAMS, P. H. (2000): Resuscitation by ferrioxamine E of stressed Salmonella enterica serovar typhimurium from soil and water microcosms. Appl. Environ. Microbiol., 66 (9): 
4128 - 4130. DOI: 10.1128/AEM.66.9.4128-4130.2000

SANTAMARÍA, J., TORANZOS, G. A. (2003): Enteric pathogens and soil: a short review. Int. Microbiol., 6 (1): 5 - 9 . DOI: $10.1007 / \mathrm{s} 10123-003-0096-1$

STATISTICA 6.0, StatSoft Inc., USA.

TURNER, C. (2002): The thermal inactivation of E. coli in straw and pig manure. Bioresource Technol., 84 (1): 57 - 61 Schikora, A., CArreri, A., Charpentier, E., Hirt, H. (2008): The dark side of the salad: Salmonella typhimurium overcomes the innate immune response of Arabidopsis thaliana and shows an endopathogenic lifestyle.
PLoS ONE, 3: e2279. DOI: 10.1371/journal.pone.0002279 VenglovskÝ, J., Martinez, J., PlachÁ, I. (2006): Hygienic and ecological risks connected with utilization of animal manures and biosolids in agriculture. Livest. Sci., 102 (3): 197 - 203. DOI: 10.1016/j.livsci.2006.03.017

VenglovskÝ, J., SAsákovÁ, N., Plachá, I. (2009): Pathogens and antibiotic residues in animal manures and hygienic and ecological risks related to subsequent land application. Bioresource Technol., 100 (22): 5386 - 5391. DOI: 10.1016/j.biortech.2009.03.068 